\title{
Fatty acid composition in muscles from lambs fed diets containing agroindustrial co-products
}

\author{
Marcus Andrade Wanderley Junior ${ }^{1,4^{*}}$ (iD, Cristiane Leal dos Santos ${ }^{2}$, Ivon Pinheiro Lôbo ${ }^{3}$ iD, \\ Rodrigo Soares Junqueira ${ }^{4}$ (iD), Leandro Pereira Lima ${ }^{4}$ iD), Thon Jovita Farias ${ }^{4}$ (D), \\ Jeferson Ladeia dos Santos ${ }^{5}$, Andrezza Miguel da Silva ${ }^{4}$
}

\footnotetext{
${ }^{1}$ Instituto Federal de Educação, Ciência e Tecnologia da Bahia, Departamento de Ensino, Porto Seguro, BA, Brasil.

${ }^{2}$ Universidade Estadual do Sudoeste da Bahia, Departamento de Tecnologia Rural e Animal, Itapetinga, BA, Brasil.

${ }^{3}$ Universidade Estadual de Santa Cruz, Departamento de Ciências Exatas e Tecnológicas, Ilhéus, BA, Brasil.

${ }^{4}$ Universidade Estadual do Sudoeste da Bahia, Programa de Pós-graduação em Zootecnia, Itapetinga, BA, Brasil.

${ }^{5}$ Universidade Estadual do Sudoeste da Bahia, Itapetinga, BA, Brasil.
}

\begin{abstract}
The objective of this study was to evaluate the effects of supplementing diet of lambs with agroindustrial co-products on the nutritional quality of meat fat and study the variation of fat quality parameters based on the type of muscle. Twenty lambs were distributed into four experimental groups and fed a control diet or diets containing cottonseed, sunflower meal, and castor cake. After 106 experimental days, the animals were slaughtered. Samples of Biceps femoris, Longissimus dorsi, Semimembranosus, and Triceps brachii muscles were taken for fatty acid and cholesterol analyses. Castor cake and sunflower meal diets produced meats with lower levels of n-6 polyunsaturated fatty acids (PUFA) compared with the control diet. Castor cake diet contributed to tissue reduction of n-3 PUFA. Lower conjugated linoleic acid concentration and polyunsaturated:saturated fatty acid $(\mathrm{P}: \mathrm{S})$ ratio and higher saturated fatty acids content and Thrombogenicity Index were observed in Longissimus dorsi meat. Of the co-products studied, although castor cake diet reduced cholesterol levels in Biceps femoris muscle, sunflower meal was identified as the preferred choice for lamb feeding, since it reduced n- 6 PUFA without, however, decreasing n-3 PUFA. Longissimus dorsi meat had the lowest fat quality indexes. The more oxidative muscles, such as Biceps femoris, tend to generate meats with higher cholesterol concentrations.
\end{abstract}

Key Words: castor cake, cholesterol, cottonseed, sunflower meal

\section{Introduction}

The nutritional quality of animal fat is determined by its fatty acid composition. In the case of ruminants, numerous strategies have been used to promote beneficial changes in the fatty acid profile of meat, such as modification of animal diet.

Currently, a variety of oilseed co-products are used to feed sheep, including castor cake (Alves et al., 2016), sunflower meal (Majewska et al., 2016), and cottonseed (Paim et al., 2014). These co-products, besides being a good source of protein, have a high fat content, consisting of polyunsaturated fatty acids (PUFA). Thus, these co-products

Received: January 15, 2018

Accepted: June 10, 2018

*Corresponding author: marcusjr_w@yahoo.com.br

Copyright (c) 2018 Sociedade Brasileira de Zootecnia. This is an Open Access article distributed under the terms of the Creative Commons Attribution License (http://creativecommons.org/licenses/by/4.0/), which permits unrestricted use, distribution, and reproduction in any medium, provided the original work is properly cited. have the potential to improve meat fat, with a direct consequence on its nutritional value and acceptability.

In general, the nutritional improvement of meat fat involves a reduction in the concentration of saturated fatty acids (SFA), which are associated with coronary diseases, and n-6 PUFA, which are pro-inflammatory. Meat quality can also be improved by increasing the concentration of n-3 PUFA and conjugated linoleic acid (CLA) isomers, associated with protection against cancer, diabetes, and cardiovascular diseases (Koba and Yanagita, 2014; Lands 2014; Zong et al., 2016).

Strategies for lipid meat modification are important because red meat consumption has often been related to the development of cardiovascular diseases (Gomide et al., 2013) due to the quantity and quality of its fat.

In this study, we aimed to evaluate the effects of supplementing the diet of lambs with agroindustrial coproducts (cottonseed, sunflower meal, and castor cake) on the nutritional quality of meat fat and study the variation of fat quality parameters based on the type of muscle. 


\section{Material and Methods}

All experimental procedures involving animals were conducted in accordance with the Committee of Animal Ethics (case no. 24/2013). The study was conducted in

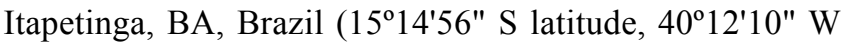
longitude, and $270 \mathrm{~m}$ elevation). Twenty Dorper $\times$ Santa Ines lambs, neutered males, approximately 90 days old, and with an average body weight of $20.1 \pm 2.5 \mathrm{~kg}$ were used. Animals were randomly distributed into four experimental groups. Lambs were kept in individual stalls, equipped with a trough and drinking fountain in a covered stable. Experimental diets were formulated according to the Nutrient Requirements of Small Ruminants (NRC, 2007, Washington, DC, USA) for an average daily gain of $200 \mathrm{~g}$. A conventional concentrate (control diet) was used, based on ground corn, soybean meal, urea, and mineral supplement, with partial substitution of soybean meal and corn with one of three agroindustrial co-products: cottonseed, sunflower meal, or detoxified castor cake with aqueous solution of calcium hydroxide $\left[\mathrm{Ca}(\mathrm{OH})_{2}\right.$ 1:10 (w/v)] (Table 1). Diets were formulated to maintain protein and energy balance with a concentrate:voluminous ratio of 50:50 with hay made from Tifton-85 grass (Cynodon spp).

Diets were provided ad libitum, representing $4.5 \%$ of body weight as a complete blend. Animals were fed twice per day, in equal portions, at 7:00 and 15:00 h, admitting

Table 1 - Proportion of ingredients and chemical composition of experimental diets

\begin{tabular}{|c|c|c|c|c|}
\hline & \multicolumn{4}{|c|}{$\operatorname{Diet}^{1}$} \\
\hline & Control & CS & SFM & $\mathrm{CC}$ \\
\hline \multicolumn{5}{|l|}{ Ingredient ( $\left.\mathrm{g} \mathrm{kg}^{-1} \mathrm{DM}\right)$} \\
\hline Tifton-85 hay & 500.0 & 500.0 & 500.0 & 500.0 \\
\hline Ground corn & 365.0 & 305.0 & 345.0 & 345.0 \\
\hline Soybean meal & 120.0 & 80.0 & 60.0 & 60.0 \\
\hline Cottonseed & - & 100.0 & - & - \\
\hline Sunflower meal & - & - & 80.0 & - \\
\hline Castor cake & - & - & - & 80.0 \\
\hline Urea & 10.0 & 10.0 & 10.0 & 10.0 \\
\hline Mineral supplement ${ }^{2}$ & 5.0 & 5.0 & 5.0 & 5.0 \\
\hline \multicolumn{5}{|c|}{ Chemical composition ( $\left.\mathrm{g} \mathrm{kg}^{-1} \mathrm{DM}\right)$} \\
\hline Dry matter & 861.8 & 866.3 & 874.4 & 858.1 \\
\hline Organic matter & 944.1 & 942.8 & 942.9 & 936.7 \\
\hline Crude protein & 166.8 & 166.6 & 165.6 & 166.9 \\
\hline Ether extract & 28.5 & 23.4 & 20.2 & 22.1 \\
\hline Mineral matter & 55.9 & 57.2 & 57.1 & 63.3 \\
\hline Neutral detergent fiber & 591.1 & 594.8 & 571.1 & 579.3 \\
\hline Non-fibrous carbohydrates & 317.7 & 317.5 & 339.9 & 341.4 \\
\hline Total carbohydrates & 748.8 & 752.8 & 757.1 & 747.7 \\
\hline \multicolumn{5}{|c|}{$\begin{array}{l}{ }^{1} \text { CS: cottonseed; SFM: sunflower meal; CC: castor cake. } \\
{ }^{2} \text { Composition (supplement per kg) = calcium, } 155 \mathrm{~g} \text {; phosphorus, } 65 \mathrm{~g} \text {; sodium } \\
155 \mathrm{~g} \text {; sulfur, } 12 \mathrm{~g} \text {; magnesium, } 6 \mathrm{~g} \text {; copper, } 100 \mathrm{mg} \text {; cobalt, } 175 \mathrm{mg} \text {; iron, } 1000 \mathrm{mg} \\
\text { iodine, } 175 \mathrm{mg} \text {; manganese, } 1400 \mathrm{mg} \text {; selenium, } 27 \mathrm{mg} \text {; zinc, } 6000 \mathrm{mg} \text {; nickel } \\
42 \mathrm{mg} \text {; fluorine, } 650 \mathrm{mg} \text {. } \\
\text { Source: Silva (2015). }\end{array}$} \\
\hline
\end{tabular}

$20 \%$ of leftovers. The total quantity of feed supplied was adjusted daily, based on the amount of leftovers from the previous day to provide voluntary intake. A trial period of 106 days was established, with 14 days of adaptation to the experimental conditions (diet and management). Animals were identified and dewormed during the adaptation period.

At the end of the experimental period, after a 16-h fasting period, animals were slaughtered using procedures according to Regulations of the Serviço de Inspeção Federal. Slaughter was performed using the method of cerebral concussion desensitization, followed by bleeding, which involved severing the jugular and carotid veins. Animals were skinned and eviscerated with subsequent removal of the paws, head, and testicles, obtaining the entire carcass. Whole carcasses were then chilled at $4{ }^{\circ} \mathrm{C}$ for $24 \mathrm{~h}$, longitudinally sectioned, and samples were taken from the Biceps femoris (BF), Longissimus dorsi (LD), Semimembranosus (SM), and Triceps brachii (TB) of the right half of each carcass without removal of subcutaneous or intermuscular fat, for physical and chemical analyses; the samples to be analyzed $(n=20)$ presented a mean fat content

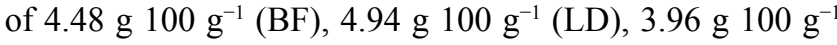

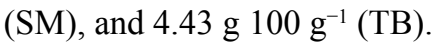

The lipid fraction of meat samples was determined using the Bligh and Dyer (1959) method. The lipid fraction of experimental diets was determined using the method proposed by Folch et al. (1957). Lipids were transesterified (method 5509; ISO, 1978) to obtain fatty acid methyl esters (FAME). Approximately $200 \mathrm{mg}$ of fat extracted from meat samples and experimental diets were weighed in screw-cap glass tubes. The following reagents were then added: $2 \mathrm{~mL}$ of $\mathrm{n}$-heptane, $1 \mathrm{~mL}$ of the methyl tridecanoate (C13:0) solution at $2 \mathrm{mg} / \mathrm{mL}$ (internal standard), and $2 \mathrm{~mL}$ of a $2 \mathrm{M}$ solution of $\mathrm{KOH}$ in methanol. The tube was closed, shaken vigorously for $5 \mathrm{~min}$, and left to rest for $1 \mathrm{~h}$ for phase separation. Finally, an aliquot of approximately $1.5 \mathrm{~mL}$ from the upper phase was transferred to a vial and stored at $-10{ }^{\circ} \mathrm{C}$ until chromatographic analysis.

Fatty acid methyl esters were analyzed using a gas chromatograph (Varian CP-3800) equipped with a flame ionization detector and a CP-SIL 88 fused silica capillary column $(100 \mathrm{~m}, 0.25 \mathrm{~mm}$ internal diameter and $0.2 \mu \mathrm{m}$ film). The total chromatographic run time was $71.25 \mathrm{~min}$, divided into three heating ramps as follows: $120^{\circ} \mathrm{C}(10$ $\min ), 190{ }^{\circ} \mathrm{C}\left(3{ }^{\circ} \mathrm{C} \mathrm{min}-1,5 \mathrm{~min}\right), 210{ }^{\circ} \mathrm{C}\left(1{ }^{\circ} \mathrm{C} \mathrm{min}^{-1}\right)$, and $240{ }^{\circ} \mathrm{C}\left(10{ }^{\circ} \mathrm{C} \mathrm{min}^{-1}, 10 \mathrm{~min}\right)$. The injector and detector temperatures were 250 and $290{ }^{\circ} \mathrm{C}$, respectively, using a 1:120 split ratio and $1.0 \mu \mathrm{L}$ injection volume. 
The identification of fatty acids was based on a comparison with the retention times of a standard mixture of 37 FAME (18919 Supelco, USA) and linoleic acid geometric isomers c9t11 and t10c12 (O5632 Sigma, USA).

The quantification of fatty acids from meat samples and

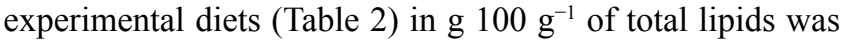
performed based on Sigma's internal methyl tridecanoate (C13:0) standard, added to the samples at the start of the transesterification procedure.

Cholesterol analysis of meat samples was performed in two stages: sample preparation (direct saponification and extraction of the unsaponifiable fraction), according to the methodology proposed by Saldanha et al. (2006), with some modifications, followed by chromatographic quantification of cholesterol.

Two grams of meat, previously ground, was placed in a test tube with a screw-cap with $4 \mathrm{~mL}$ of $50 \% \mathrm{KOH}$ solution and $6 \mathrm{~mL}$ of ethyl alcohol. The mixture was then vortexed for $1 \mathrm{~min}$ and kept in the dark for $22 \mathrm{~h}$ for the complete saponification reaction. Next, $5 \mathrm{~mL}$ of distilled water and $10 \mathrm{~mL}$ of hexane p.a. were added. The mixture was vortexed again for $5 \mathrm{~min}$ and kept in the dark for $1 \mathrm{~h}$ until phase separation. The upper hexane fraction was collected, transferred to a flat-bottomed flask, and evaporated in a rotary evaporator (water bath temperature $33-34{ }^{\circ} \mathrm{C}$ ). The remaining residue was diluted with $2.5 \mathrm{~mL}$ of mobile phase (acetonitrile:isopropanol 85:15 v/v, chromatographic grade), passed through a $25-\mathrm{mm}$ syringe micro-filter $\left(\right.$ Chromafil $\left.{ }^{\circledR}\right)$ with a polytetrafluoroethylene (PTFE) filter membrane (pore size $0.45 \mu \mathrm{m}$ ), and analyzed

Table 2 - Average content $\left(\mathrm{g} 100 \mathrm{~g}^{-1}\right)$ of fatty acids of the four experimental concentrates

\begin{tabular}{lcccc}
\hline & \multicolumn{4}{c}{ Concentrate $^{1}$} \\
\cline { 2 - 5 } Fatty acid (g $100 \mathrm{~g}^{-1}$ ) & Control & CS & SFM & CC \\
\hline c14:0 (myristic acid) & 0.04 & 0.35 & 0.07 & 0.08 \\
c16:0 (palmitic acid) & 11.91 & 16.08 & 10.36 & 11.44 \\
c16:1 (palmitoleic acid) & 0.11 & 0.26 & 0.13 & 0.12 \\
c17:0 (margaric acid) & 0.07 & 0.09 & 0.08 & 0.09 \\
c17:1 (heptadecenoic acid) & 0.00 & 0.03 & 0.09 & 0.02 \\
c18:0 (stearic acid) & 1.95 & 2.10 & 1.98 & 1.97 \\
c18:1 n9t (elaidic acid) & 0.00 & 0.12 & 0.00 & 0.02 \\
c18:1 n9c (oleic acid) & 24.84 & 19.37 & 24.59 & 22.96 \\
c18:2 n6c (linoleic acid) & 34.90 & 39.35 & 30.34 & 28.58 \\
c20:0 (arachidic acid) & 0.49 & 0.32 & 0.43 & 0.46 \\
c20:1 (gadoleic acid) & 0.18 & 0.10 & 0.17 & 0.16 \\
c18:3 n3 (linolenic acid) & 1.18 & 0.60 & 0.79 & 0.79 \\
c22:0 (behenic acid) & 0.22 & 0.15 & 0.23 & 0.20 \\
c20:3 n6 (dihomo- $\gamma$-linolenic acid) & 0.02 & 0.00 & 0.00 & 0.00 \\
c20:4 n6 (arachidonic acid) & 0.00 & 0.00 & 0.01 & 0.00 \\
c24:0 (lignoceric acid) & 0.19 & 0.12 & 0.18 & 0.18 \\
c22:6 n3 (docosahexaenoic acid) & 0.04 & 0.01 & 0.04 & 0.06 \\
Saturated fatty acids & 14.88 & 19.21 & 13.34 & 14.49 \\
Polyunsaturated fatty acids & 36.14 & 39.96 & 31.18 & 29.43 \\
\hline c5: cotonseed; SFM: & & &
\end{tabular}

${ }^{1}$ CS: cottonseed; SFM: sunflower meal; CC: castor cake. by high-performance liquid chromatography (HPLC) for quantification of cholesterol.

A liquid chromatograph (Shimadzu) was used, with an analytical column $\mathrm{C} 18(15 \mathrm{~cm} \times 4.6 \mathrm{~mm} \times 5 \mu \mathrm{m})$ coupled to a UV spectrophotometric detector at $202 \mathrm{~nm}$. The oven temperature was adjusted to $40{ }^{\circ} \mathrm{C}$ and the analysis time to $10 \mathrm{~min}$. The mobile phase used was acetonitrile:isopropanol $85: 15(\mathrm{v} / \mathrm{v})$, with a constant flow rate of $2.0 \mathrm{~mL} \mathrm{~min}^{-1}$. Injections of $100 \mu \mathrm{L}$ were performed in duplicate, and cholesterol peak areas were determined using LCSolution ${ }^{\circledR}$ software. Cholesterol was identified by comparing peak retention time of the samples with the cholesterol standard (Cholesterol, code C8667, Sigma-Aldrich ${ }^{\circledR}$ ). Quantification (mg $100 \mathrm{~g}^{-1}$ ) was performed by applying the integrated areas of peaks obtained from the equation of the straight line produced on the calibration curve, fitted with the cholesterol standard.

A split-plot scheme in space was used, with the experimental diets $\left(\mathrm{A}_{\mathrm{i}}\right)$ completely randomized into plots, and the muscle $\left(\mathrm{B}_{\mathrm{j}}\right)$ and the interaction $(\mathrm{AB})_{\mathrm{ij}}$ in the subplots, with 5 replicates, as follows:

$$
\mathrm{Y}_{\mathrm{ijk}}=\mu+\mathrm{A}_{\mathrm{i}}+\delta_{\mathrm{ik}}+\mathrm{B}_{\mathrm{j}}+(\mathrm{AB})_{\mathrm{ij}}+\mathrm{e}_{\mathrm{ijk}}
$$

Data were subjected to analysis of variance (ANOVA). The effect of the plot $\left(\mathrm{A}_{\mathrm{i}}\right)$ was evaluated with the experimental error associated with it $\left(\delta_{\mathrm{ik}}\right)$, and the effect of the subplot $\left(\mathrm{B}_{\mathrm{j}}\right)$ and the interaction $(\mathrm{AB})_{\mathrm{ij}}$ were tested based on the experimental error of the subplot $\left(\mathrm{e}_{\mathrm{ijk}}\right)$. The interaction, when significant $(\mathrm{P}<0.05)$, was dismembered, and the following analyses were conducted: for comparison between levels of $B$ at the same level of $A$, we used $e_{i j k}$; the levels of A at each level of B were tested using a combined error, as proposed by Satterthwait (1946); the means of the factors, in the case of significant dismemberment, were compared using the Tukey test $(\mathrm{P}<0.05)$; for non-significant interactions, the means of the individual factors ( $\mathrm{A}$ and $\mathrm{B})$, when significantly different $(\mathrm{P}<0.05)$, were compared using the Tukey test $(\mathrm{P}<0.05)$. The GLM procedure from the SAS (Statistical Analysis System, University Edition) package was used for all analyses.

\section{Results}

The use of agroindustrial co-products did not modify $(\mathrm{P}>0.05)$ the tissue levels of the main SFA found. Only behenic acid $(\mathrm{C} 22: 0)$ had its concentration reduced $(\mathrm{P}<0.05)$ by cottonseed and castor cake diets (Table 3 ). Longissimus dorsi meat had a higher $(\mathrm{P}<0.05)$ concentration of palmitic acid $(\mathrm{C} 16: 0)$ than $\mathrm{BF}$ meat. A higher $(\mathrm{P}<0.05)$ stearic acid (C18:0) concentration was detected in $\mathrm{LD}$ than in $\mathrm{BF}, \mathrm{SM}$, and TB meats (Table 3). Together, C16:0 and C18:0 represented 
Table 3 - Average content of saturated fatty acids and their largest grouping in muscles of Dorper $\times$ Santa Ines lambs subjected to diets with agroindustrial co-products

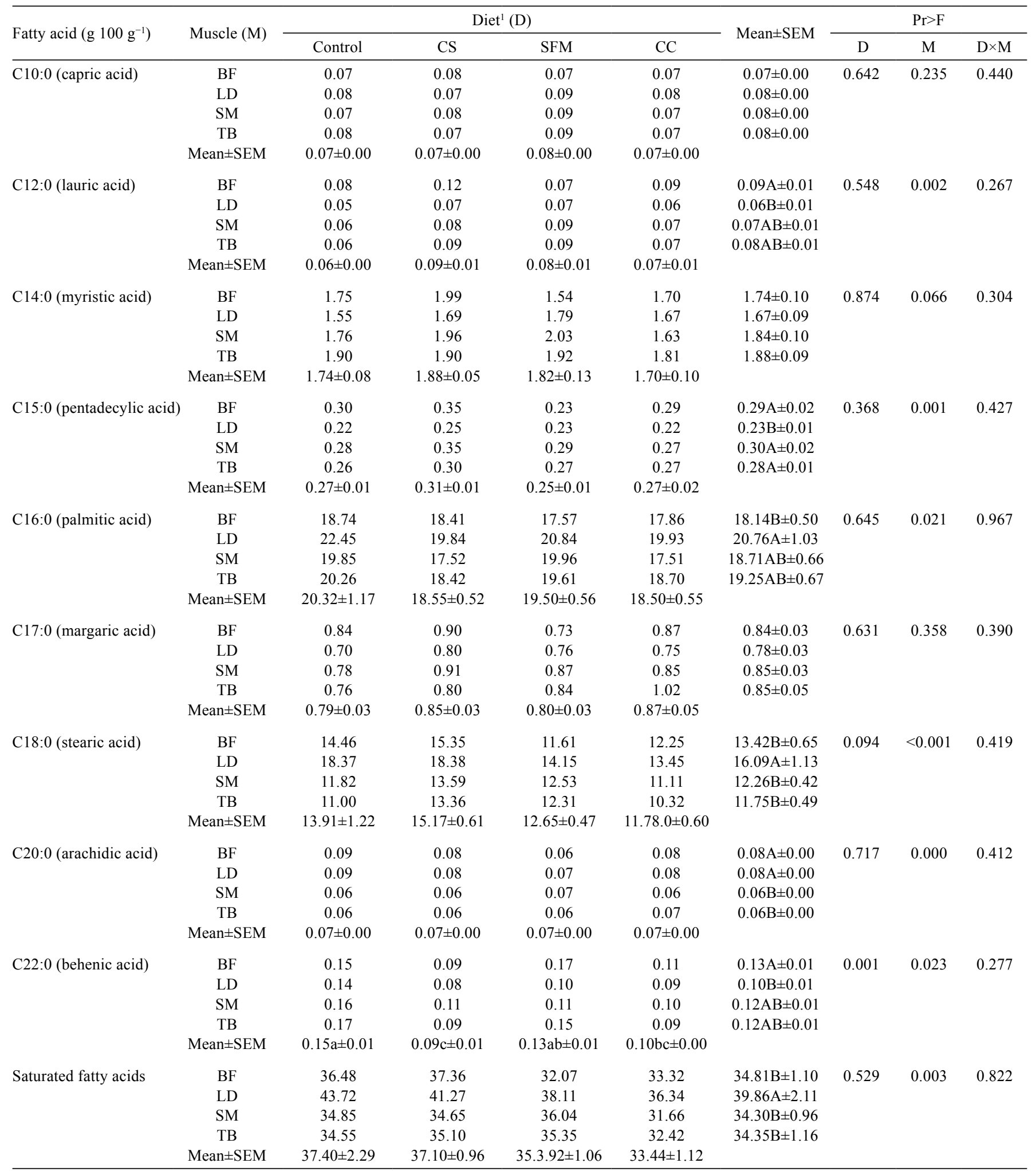

BF - Biceps femoris; LD - Longissimus dorsi; SM - Semimembranosus; TB - Triceps brachii.

${ }^{1}$ CS: cottonseed; SFM: sunflower meal; CC: castor cake.

Mean $(n=20) \pm$ standard error of the mean.

Means followed by the same letter in the rows (a-c) or columns (A-C) do not differ $(\mathrm{P}>0.05)$ by the Tukey test. 
about $91 \%$ of the SFA and $44 \%$ of all identified fatty acids. In general, higher $(\mathrm{P}<0.05)$ SFA concentration was detected in LD than in BF, SM, and TB meats (Table 3).

The castor cake and sunflower meal diets promoted higher $(\mathrm{P}<0.05) \Delta-9$ desaturase $\mathrm{C} 18$ activity compared with the cottonseed diet. Minor $(\mathrm{P}<0.05) \Delta-9$ desaturase activity was verified in LD than in BF, SM, and TB meats (Table 4).

As for SFA, the agroindustrial co-products used did not modify ( $\mathrm{P}<0.05)$ the tissue levels of the main MUFA found. Only gadolenic acid (C20:1) had its concentration reduced with inclusion of cottonseed. We detected no significant differences $(\mathrm{P}>0.05)$ in the total MUFA concentrations between the experimental diets or tested meats (Table 5). Oleic acid $(\mathrm{C} 18: 1 \mathrm{n} 9 \mathrm{c})$ represented about $91.31 \%$ of the MUFA and $44.51 \%$ of all identified fatty acids.

Longissimus dorsi meat had lower $(\mathrm{P}<0.05)$ concentrations of myristoleic $(\mathrm{C} 14: 1)$ and palmitoleic (C16:1) acids compared with SM and TB, and a lower $(\mathrm{P}<0.05)$ concentration of heptadecanoic acid $(\mathrm{C} 17: 1)$ than BF, SM, and TB (Table 5).

For PUFA, the control and cottonseed diets promoted higher $(\mathrm{P}<0.05)$ concentrations of $\mathrm{C} 18: 2 \mathrm{n} 6 \mathrm{c}$ and total PUFA compared with the castor cake diet. We detected no significant differences $(\mathrm{P}>0.05)$ in the $\mathrm{C} 18: 3 \mathrm{n} 3$ concentrations among the experimental diets. Higher $(\mathrm{P}<0.05)$ concentration of arachidonic acid $(\mathrm{C} 20: 4 \mathrm{n} 6)$ was observed in the animals receiving the control diet. The castor cake and sunflower meal diets resulted in lower $(\mathrm{P}<0.05)$ tissue concentrations of total n-6 PUFA than the control diet. Lower $(\mathrm{P}<0.05)$ tissue concentration of $\mathrm{n}-3$ PUFA was observed in the animals receiving the castor cake diet compared with those that received the control diet (Table 6).

Meat of BF showed the highest $(\mathrm{P}<0.05)$ concentration of linoleic $(\mathrm{C} 18: 2 \mathrm{n} 6 \mathrm{c})$ and linolenic $(\mathrm{C} 18: 3 \mathrm{n} 3)$ acids than meat of LD, SM, and TB. Lower $(\mathrm{P}<0.05)$ concentrations of CLA, represented by $\mathrm{C} 18: 2 \mathrm{n} 9 \mathrm{c} 11 \mathrm{t}$ isomer, and total PUFA were observed in LD than in BF, SM, and TB meats. For the $n-3$ and $n-6$ PUFA, the LD meat had a lower $(P<0.05)$ concentration than the BF meat (Table 6).

We detected a larger $(\mathrm{P}<0.05) \mathrm{n} 6: \mathrm{n} 3$ ratio in TB than in $\mathrm{SM}$ meat. A lower $(\mathrm{P}<0.05)$ polyunsaturated:saturated fatty acid (P:S) ratio was observed in LD than in $\mathrm{BF}, \mathrm{SM}$, and TB meats (Table 7).

An effect of an interaction $(\mathrm{P}<0.05)$ was observed for the cholesterol concentration. With the cottonseed diet, $\mathrm{BF}$ muscle meat contained the highest cholesterol concentration. With the control and sunflower meal diets, $\mathrm{BF}$ muscle meat contained the highest cholesterol concentration than SM and TB. On the other hand, in the BF muscle, lower cholesterol concentration was verified with the castor cake diet compared with the other diets (Table 7).

\section{Discussion}

Of the SFA, greater attention has been given to the C16:0 acid because of its potential for hypercholesterolemic action (Zock et al., 1994), and to C18:0, which reduces

Table 4 - Indexes of desaturase activities in muscles of Dorper $\times$ Santa Ines lambs subjected to diets with agroindustrial co-products

\begin{tabular}{|c|c|c|c|c|c|c|c|c|c|}
\hline & \multirow{2}{*}{ Muscle (M) } & \multicolumn{4}{|c|}{$\operatorname{Diet}^{1}(\mathrm{D})$} & \multirow{2}{*}{ Mean \pm SEM } & \multicolumn{3}{|c|}{$\operatorname{Pr}>\mathrm{F}$} \\
\hline & & Control & $\mathrm{CS}$ & SFM & $\mathrm{CC}$ & & $\mathrm{D}$ & M & $\mathrm{D} \times \mathrm{M}$ \\
\hline \multirow[t]{5}{*}{$\Delta-9$ desaturase $\mathrm{C} 14$} & $\mathrm{BF}$ & 2.80 & 2.61 & 3.39 & 2.73 & $2.88 \mathrm{~B} \pm 0.16$ & 0.148 & $<0.001$ & 0.098 \\
\hline & LD & 2.23 & 1.63 & 2.87 & 2.57 & $2.32 \mathrm{C} \pm 0.13$ & & & \\
\hline & SM & 3.75 & 3.48 & 3.24 & 3.50 & $3.49 \mathrm{~A} \pm 0.16$ & & & \\
\hline & TB & 3.91 & 3.05 & 3.44 & 3.37 & $3.44 \mathrm{~A} \pm 0.14$ & & & \\
\hline & Mean \pm SEM & $3.17 \pm 0.21$ & $2.69 \pm 0.18$ & $3.24 \pm 0.15$ & $3.04 \pm 0.16$ & & & & \\
\hline \multirow[t]{5}{*}{$\Delta-9$ desaturase $\mathrm{C} 16$} & $\mathrm{BF}$ & 7.57 & 6.70 & 7.64 & 7.54 & $7.36 \mathrm{~A} \pm 0.18$ & 0.608 & $<0.001$ & 0.087 \\
\hline & LD & 5.64 & 5.41 & 6.58 & 6.62 & $6.06 \mathrm{~B} \pm 0.21$ & & & \\
\hline & SM & 8.04 & 8.43 & 7.67 & 7.70 & $7.96 \mathrm{~A} \pm 0.28$ & & & \\
\hline & TB & 8.81 & 7.37 & 7.33 & 7.14 & $7.66 \mathrm{~A} \pm 0.30$ & & & \\
\hline & Mean \pm SEM & $7.51 \pm 0.33$ & $6.98 \pm 0.37$ & $7.30 \pm 0.15$ & $7.25 \pm 0.28$ & & & & \\
\hline \multirow[t]{5}{*}{$\Delta-9$ desaturase $\mathrm{C} 18$} & $\mathrm{BF}$ & 69.18 & 67.55 & 75.08 & 72.69 & $71.12 \mathrm{~B} \pm 1.23$ & 0.002 & $<0.001$ & 0.053 \\
\hline & LD & 64.30 & 62.95 & 72.09 & 71.36 & $67.67 \mathrm{C} \pm 1.23$ & & & \\
\hline & SM & 73.97 & 70.46 & 73.54 & 73.97 & $72.93 \mathrm{AB} \pm 0.61$ & & & \\
\hline & TB & 75.72 & 69.82 & 73.26 & 76.71 & $73.67 \mathrm{~A} \pm 0.78$ & & & \\
\hline & Mean \pm SEM & $70.79 \mathrm{ab} \pm 1.31$ & $67.69 \mathrm{~b} \pm 1.11$ & $73.49 \mathrm{a} \pm 7.56$ & $73.68 \mathrm{a} \pm 0.81$ & & & & \\
\hline
\end{tabular}

BF - Biceps femoris; LD - Longissimus dorsi; SM - Semimembranosus; TB - Triceps brachii.

${ }^{1} \mathrm{CS}$ : cottonseed; SFM: sunflower meal; CC: castor cake.

Mean $(n=20) \pm$ standard error of the mean.

Means followed by the same letter in the rows (a-c) or columns (A-C) do not differ $(\mathrm{P}>0.05)$ by the Tukey test.

$\Delta-9$ desaturase $\mathrm{C} 14=100[\mathrm{C} 14: 1 /(\mathrm{C} 14: 1+\mathrm{C} 14: 0)] ; \Delta-9$ desaturase $\mathrm{C} 16=100[\mathrm{C} 16: 1 /(\mathrm{C} 16: 1+\mathrm{C} 16: 0)] ; \Delta-9$ desaturase $\mathrm{C} 18=100[\mathrm{C} 18: 1 \mathrm{n} 9 \mathrm{c} /(\mathrm{C} 18: 1 \mathrm{n} 9 \mathrm{c}+18: 0)]$. 
HDL cholesterol levels (Schwab et al., 1996). Variation in the tissue concentration of $\mathrm{C} 16: 0$ is mainly due to the endogenous synthesis of fatty acids, known as new synthesis or lipogenesis, which, in non-lactating ruminants, occurs mainly in adipose tissue. For this process, $50-80 \%$ of all required NADPH is derived from glucose oxidation via the pentose phosphate pathway (Nafikov and Beitz, 2007). Thus, predominantly oxidative muscles such as BF tend to provide lower $\mathrm{C} 16: 0$ levels, because they present a lower concentration of glycogen compared with muscles of intermediate to glycolytic metabolic activity, such as LD (Briand et al., 1981; Gomide et al., 2013; Johnsen et al., 2013). The higher tissue concentration of C18:0 in LD meat is related to the lower indexes of $\Delta-9$ desaturase (Table 4 ), which is responsible for C18:0 desaturation to C18:1n9c (Choi et al., 2013).

The lower concentrations of C14:1 and C16:1 in the LD than in SM and TB meats (Table 5) might be associated with its lower $\Delta 9$ desaturase $\mathrm{C} 14$ and $\mathrm{C} 16$ activities (Table 4). According to Smith et al. (2009), only $\Delta-9$ desaturase is able to act on SFA by converting them to MUFA.

The highest concentration of $\mathrm{C} 18: 2 \mathrm{n} 6 \mathrm{c}$ and $\mathrm{C} 18: 3 \mathrm{n} 3$, which occurred in BF meat (Table 6), may be related to its muscle metabolism. In sheep, the BF muscle is characterized by its oxidative metabolism (Johnsen et al., 2013), with LD and SM considered to have intermediate to glycolytic metabolism (Briand et al., 1981; Ithurralde et al., 2015) and

Table 5 - Average content of monounsaturated fatty acids and their largest group in muscles of Dorper $\times$ Santa Ines lambs subjected to diets with agroindustrial co-products

\begin{tabular}{|c|c|c|c|c|c|c|c|c|c|}
\hline \multirow{2}{*}{ Fatty acid (g $\left.100 \mathrm{~g}^{-1}\right)$} & \multirow{2}{*}{ Muscle (M) } & \multicolumn{4}{|c|}{$\operatorname{Diet}^{1}(\mathrm{D})$} & \multirow{2}{*}{ Mean \pm SEM } & \multicolumn{3}{|c|}{$\operatorname{Pr}>\mathrm{F}$} \\
\hline & & Control & $\mathrm{CS}$ & SFM & $\mathrm{CC}$ & & $\mathrm{D}$ & M & $\mathrm{D} \times \mathrm{M}$ \\
\hline \multirow[t]{5}{*}{ C14:1 (myristoleic acid) } & $\mathrm{BF}$ & 0.05 & 0.05 & 0.05 & 0.05 & $0.05 \mathrm{~B} \pm 0.00$ & 0.742 & $<0.001$ & 0.293 \\
\hline & LD & 0.03 & 0.03 & 0.05 & 0.04 & $0.04 \mathrm{~B} \pm 0.00$ & & & \\
\hline & SM & 0.07 & 0.07 & 0.07 & 0.06 & $0.07 \mathrm{~A} \pm 0.00$ & & & \\
\hline & TB & 0.08 & 0.06 & 0.07 & 0.06 & $0.07 \mathrm{~A} \pm 0.00$ & & & \\
\hline & $\operatorname{Mean} \pm \mathrm{SEM}$ & $0.06 \pm 0.00$ & $0.05 \pm 0.00$ & $0.06 \pm 0.00$ & $0.05 \pm 0.00$ & & & & \\
\hline \multirow[t]{5}{*}{ C16:1 (palmitoleic acid) } & $\mathrm{BF}$ & 1.53 & 1.32 & 1.45 & 1.44 & $1.44 \mathrm{AB} \pm 0.05$ & 0.206 & 0.001 & 0.082 \\
\hline & LD & 1.26 & 1.13 & 1.47 & 1.41 & $1.32 \mathrm{~B} \pm 0.05$ & & & \\
\hline & $\mathrm{SM}$ & 1.74 & 1.56 & 1.66 & 1.46 & $1.60 \mathrm{~A} \pm 0.05$ & & & \\
\hline & TB & 1.92 & 1.47 & 1.54 & 1.46 & $1.60 \mathrm{~A} \pm 0.08$ & & & \\
\hline & $\operatorname{Mean} \pm \mathrm{SEM}$ & $1.61 \pm 0.08$ & $1.37 \pm 0.06$ & $1.53 \pm 0.05$ & $1.44 \pm 0.06$ & & & & \\
\hline \multirow[t]{5}{*}{ C17:1 (heptadecenoic acid) } & $\mathrm{BF}$ & 0.42 & 0.43 & 0.48 & 0.45 & $0.46 \mathrm{~A} \pm 0.02$ & 0.645 & $<0.001$ & 0.920 \\
\hline & LD & 0.30 & 0.31 & 0.37 & 0.39 & $0.34 \mathrm{~B} \pm 0.01$ & & & \\
\hline & SM & 0.48 & 0.51 & 0.51 & 0.53 & $0.51 \mathrm{~A} \pm 0.02$ & & & \\
\hline & TB & 0.48 & 0.44 & 0.47 & 0.50 & $0.47 \mathrm{~A} \pm 0.02$ & & & \\
\hline & $\operatorname{Mean} \pm \mathrm{SEM}$ & $0.42 \pm 0.02$ & $0.42 \pm 0.03$ & $0.46 \pm 0.02$ & $0.47 \pm 0.02$ & & & & \\
\hline \multirow[t]{5}{*}{ C18:1n9t (elaidic acid) } & $\mathrm{BF}$ & 1.43 & 1.56 & 0.84 & 1.05 & $1.22 \pm 0.13$ & 0.087 & 0.253 & 0.351 \\
\hline & LD & 1.02 & 1.38 & 0.91 & 0.97 & $1.07 \pm 0.07$ & & & \\
\hline & SM & 1.10 & 1.32 & 0.97 & 1.00 & $1.10 \pm 0.07$ & & & \\
\hline & TB & 1.02 & 1.35 & 1.07 & 0.95 & $1.10 \pm 0.06$ & & & \\
\hline & $\operatorname{Mean} \pm \mathrm{SEM}$ & $1.14 \pm 0.12$ & $1.40 \pm 0.05$ & $0.95 \pm 0.06$ & $0.99 \pm 0.06$ & & & & \\
\hline \multirow[t]{5}{*}{ C18:1n9c (oleic acid) } & $\mathrm{BF}$ & 32.72 & 32.33 & 34.94 & 32.07 & $33.02 \pm 0.94$ & 0.665 & 0.997 & 0.640 \\
\hline & LD & 31.39 & 31.60 & 36.28 & 33.63 & $33.22 \pm 1.07$ & & & \\
\hline & $\mathrm{SM}$ & 33.83 & 32.55 & 34.77 & 31.55 & $33.18 \pm 1.03$ & & & \\
\hline & TB & 34.24 & 31.14 & 33.66 & 33.63 & $33.17 \pm 1.02$ & & & \\
\hline & Mean \pm SEM & $33.05 \pm 1.29$ & $31.91 \pm 1.10$ & $34.91 \pm 0.69$ & $32.72 \pm 0.73$ & & & & \\
\hline \multirow[t]{5}{*}{ C20:1 (gadoleic acid) } & $\mathrm{BF}$ & 0.04 & 0.04 & 0.05 & 0.05 & $0.05 \pm 0.00$ & 0.039 & 0.206 & 0.929 \\
\hline & LD & 0.04 & 0.03 & 0.05 & 0.05 & $0.04 \pm 0.00$ & & & \\
\hline & SM & 0.04 & 0.03 & 0.06 & 0.03 & $0.04 \pm 0.00$ & & & \\
\hline & $\mathrm{TB}$ & 0.04 & 0.03 & 0.05 & 0.04 & $0.04 \pm 0.00$ & & & \\
\hline & $\operatorname{Mean} \pm \mathrm{SEM}$ & $0.04 \mathrm{ab} \pm 0.00$ & $0.03 \mathrm{~b} \pm 0.00$ & $0.05 \mathrm{a} \pm 0.00$ & $0.04 \mathrm{ab} \pm 0.00$ & & & & \\
\hline \multirow[t]{5}{*}{ MUFA } & $\mathrm{BF}$ & 36.21 & 35.75 & 37.82 & 35.12 & $36.22 \pm 0.97$ & 0.721 & 0.970 & 0.610 \\
\hline & LD & 34.05 & 34.49 & 39.15 & 36.50 & $36.04 \pm 1.09$ & & & \\
\hline & SM & 37.26 & 36.04 & 38.04 & 34.63 & $36.49 \pm 1.08$ & & & \\
\hline & TB & 37.78 & 34.49 & 36.86 & 36.64 & $36.44 \pm 1.08$ & & & \\
\hline & Mean \pm SEM & $36.32 \pm 1.31$ & $35.19 \pm 1.15$ & $37.97 \pm 0.76$ & $35.72 \pm 0.79$ & & & & \\
\hline
\end{tabular}

BF - Biceps femoris; LD - Longissimus dorsi; SM - Semimembranosus; TB - Triceps brachii; MUFA $=\Sigma$ monounsaturated fatty acids

${ }^{1}$ CS: cottonseed; SFM: sunflower meal; CC: castor cake.

Mean $(n=20) \pm$ standard error of the mean.

Means followed by the same letter in the rows (a-c) or columns (A-C) do not differ $(\mathrm{P}>0.05)$ by the Tukey test. 
Table 6 - Average content of polyunsaturated fatty acids and their groups in muscles of Dorper $\times$ Santa Ines lambs subjected to diets with agroindustrial co-products

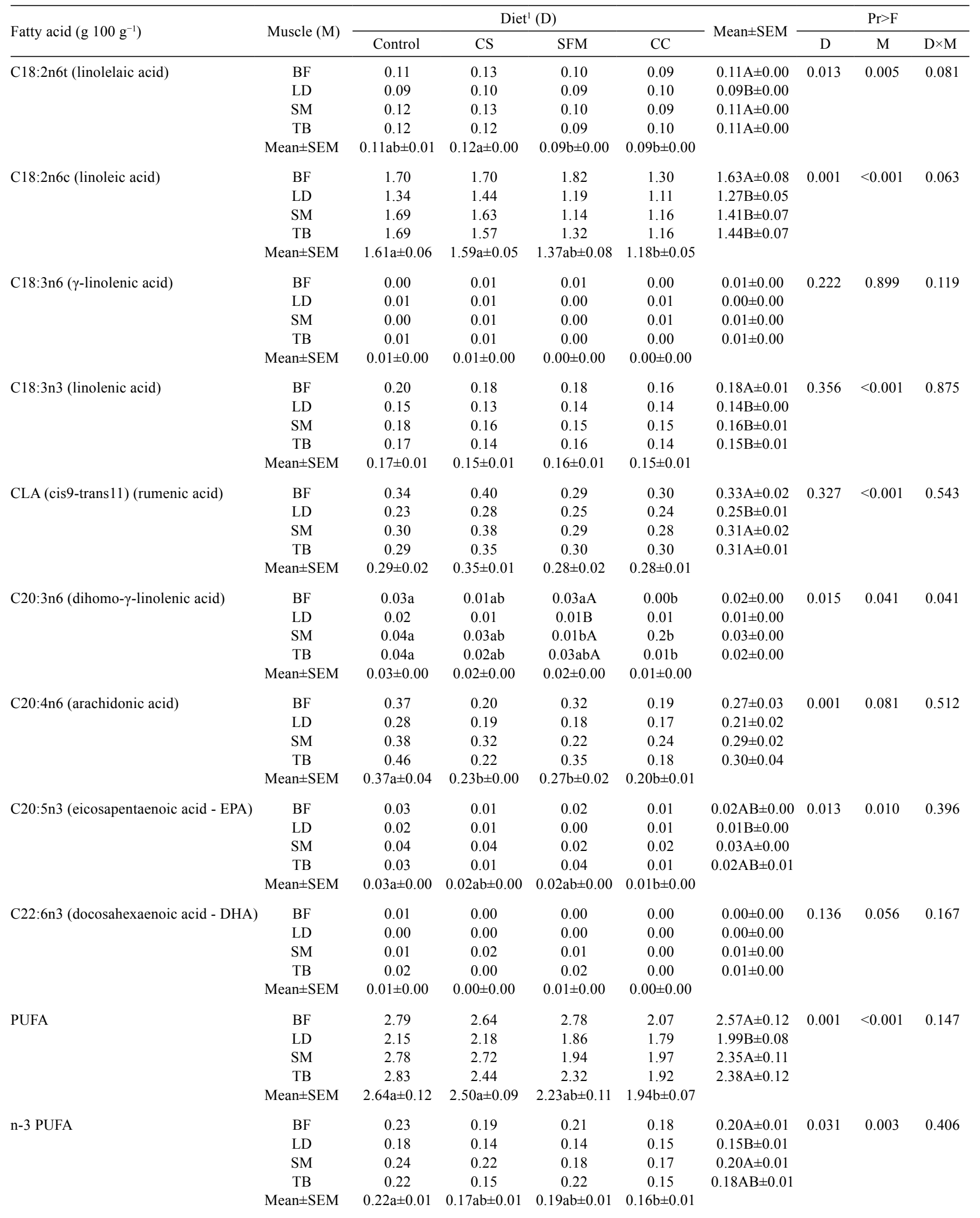


Table 6 (Continued)

\begin{tabular}{|c|c|c|c|c|c|c|c|c|c|}
\hline \multirow{2}{*}{ Fatty acid $\left({\left.\mathrm{g} 100 \mathrm{~g}^{-1}\right)}^{-1}\right.$} & \multirow{2}{*}{ Muscle (M) } & \multicolumn{4}{|c|}{$\operatorname{Diet}^{1}(\mathrm{D})$} & \multirow{2}{*}{ Mean \pm SEM } & \multicolumn{3}{|c|}{$\operatorname{Pr}>F$} \\
\hline & & Control & $\mathrm{CS}$ & SFM & $\mathrm{CC}$ & & $\mathrm{D}$ & $\mathrm{M}$ & $\mathrm{D} \times \mathrm{M}$ \\
\hline \multirow[t]{4}{*}{ n-6 PUFA } & $\mathrm{BF}$ & 2.21 & 2.05 & 2.29 & 1.59 & $2.04 \mathrm{~A} \pm 0.10$ & 0.000 & 0.001 & 0.087 \\
\hline & LD & 1.73 & 1.75 & 1.47 & 1.39 & $1.59 \mathrm{~B} \pm 0.07$ & & & \\
\hline & TB & 2.33 & 1.94 & 1.80 & 1.46 & $1.88 \mathrm{~A} \pm 0.11$ & & & \\
\hline & Mean \pm SEM & $2.13 \mathrm{a} \pm 0.10$ & $1.97 \mathrm{ab} \pm 0.07$ & $1.76 \mathrm{bc} \pm 0.10$ & $1.50 \mathrm{c} \pm 0.06$ & & & & \\
\hline
\end{tabular}

BF - Biceps femoris; LD - Longissimus dorsi; SM - Semimembranosus; TB - Triceps brachii; PUFA = $\Sigma$ polyunsaturated fatty acids; $\mathrm{n}-3$ PUFA $=\Sigma \mathrm{n}-3$ polyunsaturated fatty acids; $\mathrm{n}-6$ PUFA $=\Sigma \mathrm{n}-6$ polyunsaturated fatty acids.

${ }^{1} \mathrm{CS}$ : cottonseed; SFM: sunflower meal; CC: castor cake.

Mean $(n=20) \pm$ standard error of the mean.

Means followed by the same letter in the rows (a-c) or columns (A-C) do not differ $(\mathrm{P}>0.05)$ by the Tukey test.

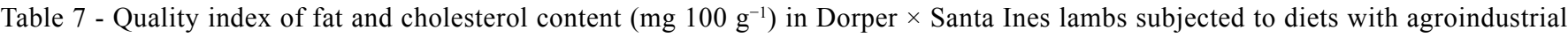
co-products

\begin{tabular}{|c|c|c|c|c|c|c|c|c|c|}
\hline & $M$ & & & & & $\mathrm{Mean+ \textrm {CFM }}$ & & $\operatorname{Pr}>F$ & \\
\hline & Nituscte (ivi) & Control & $\mathrm{CS}$ & SFM & $\mathrm{CC}$ & VTE & D & M & $\mathrm{D} \times \mathrm{M}$ \\
\hline$n-6: n-3$ & $\mathrm{BF}$ & 9.69 & 11.35 & 10.98 & 9.64 & $10.42 \mathrm{AB} \pm 0.51$ & 0.101 & 0.026 & 0.113 \\
\hline & LD & 9.68 & 12.58 & 10.42 & 9.44 & $10.53 \mathrm{AB} \pm 0.49$ & & & \\
\hline & SM & 9.73 & 10.14 & 8.56 & 8.86 & $9.32 \mathrm{~B} \pm 0.35$ & & & \\
\hline & $\mathrm{TB}$ & 10.90 & 12.94 & 8.79 & 9.64 & $10.57 \mathrm{~A} \pm 0.53$ & & & \\
\hline & Mean \pm SEM & $10.00 \pm 0.33$ & $11.75 \pm 0.56$ & $9.69 \pm 0.43$ & $9.39 \pm 0.42$ & & & & \\
\hline $\mathrm{P}: \mathrm{S}$ & $\mathrm{BF}$ & 0.05 & 0.05 & 0.07 & 0.05 & $0.05 \mathrm{~A} \pm 0.00$ & 0.094 & $<0.001$ & 0.065 \\
\hline & LD & 0.04 & 0.04 & 0.04 & 0.03 & $0.04 \mathrm{~B} \pm 0.00$ & & & \\
\hline & SM & 0.06 & 0.05 & 0.04 & 0.04 & $0.05 \mathrm{~A} \pm 0.00$ & & & \\
\hline & TB & 0.06 & 0.05 & 0.04 & 0.04 & $0.05 \mathrm{~A} \pm 0.00$ & & & \\
\hline & Mean \pm SEM & $0.05 \pm 0.00$ & $0.05 \pm 0.00$ & $0.05 \pm 0.00$ & $0.04 \pm 0.00$ & & & & \\
\hline Cholesterol & $\mathrm{BF}$ & $47.01 \mathrm{Aa}$ & $51.25 \mathrm{Aa}$ & $50.99 \mathrm{Aa}$ & $41.25 \mathrm{~b}$ & $47.63 \pm 1.05$ & 0.003 & $<0.001$ & 0.042 \\
\hline & LD & $43.77 \mathrm{AB}$ & 46.14B & $48.06 \mathrm{AB}$ & 42.82 & $45.20 \pm 0.79$ & & & \\
\hline & SM & $39.27 \mathrm{~B}$ & $41.81 \mathrm{~B}$ & $44.71 \mathrm{~B}$ & 41.56 & $41.84 \pm 0.92$ & & & \\
\hline & TB & $40.58 \mathrm{~B}$ & $45.10 \mathrm{~B}$ & $45.26 \mathrm{~B}$ & 41.85 & $43.20 \pm 0.88$ & & & \\
\hline & Mean \pm SEM & $42.66 \pm 1.01$ & $46.07 \pm 0.92$ & $47.26 \pm 0.96$ & $41.87 \pm 0.70$ & & & & \\
\hline
\end{tabular}

BF - Biceps femoris; LD - Longissimus dorsi; SM - Semimembranosus; TB - Triceps brachii; n-6:n-3 = $\Sigma$ n-6 PUFA: n-3 PUFA; P:S = (C18:2n6c + C18:3n3)/(C14:0 + C16:0 + C18:0).

${ }^{1} \mathrm{CS}$ : cottonseed; SFM: sunflower meal; CC: castor cake.

Mean $(n=20) \pm$ standard error of the mean.

Means followed by the same letter in the rows $(\mathrm{a}-\mathrm{c})$ or columns $(\mathrm{A}-\mathrm{C})$ do not differ $(\mathrm{P}>0.05)$ by the Tukey test.

TB ranging from intermediate to oxidative (Ithurralde et al., 2015). According to Wood et al. (2003), most oxidative muscles present a higher proportion of PUFA, represented mainly by $\mathrm{C} 18: 2 \mathrm{n} 6 \mathrm{c}$ and $\mathrm{C} 18: 3 \mathrm{n} 3$ acids, due to their higher phospholipidic fraction. C18:1n6c and $\mathrm{C} 18: 3 \mathrm{n} 3$ acids are precursors of n-6 and n-3 PUFA and, therefore, contribute to a higher proportion of $n-6$ and n-3 PUFA in the BF than in the LD (Table 6).

The lowest $\Delta-9$ desaturase $\mathrm{C} 18$ activity in LD meat (Table 4) may explain its lower concentration of CLA. At a tissue level, the synthesis of CLA occurs through the endogenous conversion of the vaccenic acid (C18:1t11) by the action of enzyme $\Delta-9$ desaturase (Koba and Yanagita, 2014).

Higher concentration of $\mathrm{C} 18: 2 \mathrm{n} 6 \mathrm{c}$ in animals receiving control and cottonseed diets compared with castor cake diet (Table 6) resulted from the higher supply of C18:2n6c of these diets (Table 2). In contrast to $\mathrm{C} 18: 2 \mathrm{n} 6 \mathrm{c}$, the higher content of $\mathrm{C} 18: 3 \mathrm{n} 3$ in the control diet concentrate (Table 2) did not modify $(\mathrm{P}>0.05)$ the percentage of this fatty acid in the tissues. This might be due to the fact that $\mathrm{C} 18: 2 \mathrm{n} 6 \mathrm{c}$ is preferably incorporated into the phospholipidic fraction of muscle tissue relative to $\mathrm{C} 18: 3 \mathrm{n} 3$ (Wood et al., 2008). Thus, in diets with high $\mathrm{C} 18: 2 \mathrm{n} 6 \mathrm{c}$ ratios, such as the control diet, there tends to be more difficulty incorporating C18:3n3.

Higher tissue concentration of C20:4n6 in the animals receiving the control diet was an expected result, considering that this diet provided the highest concentration of C18:2n6c (Table 2), a fatty acid precursor of $n-6$, generated by the $\Delta-5$ and $\Delta-6$ desaturases (Wood et al., 2008). However, the same effect was not observed with the cottonseed diet, which might be related to $\Delta-5$ and $\Delta-6$ desaturase enzymes, as well as $\Delta-9$ desaturase, having 
reduced activity in the presence of cyclopropenoid fatty acids, such as malvalic and sterculic, which are present in cotton oil (Cao et al., 1993; Bichi et al., 2012).

Higher content of C18:2n6c in control and cottonseed diets (Table 2) provided a higher tissue concentration of C18:2n6c, as well as n-6 PUFA, compared with castor cake diet (Table 6). In addition, the control diet provided a higher tissue concentration of n-3 PUFA than did castor cake diet (Table 6), which can be explained by the greater supply of C18:3n3 by the control (Table 2).

Despite the variation between the muscles in terms of the n-6:n-3 and P:S ratios (Table 7), which act as indicators of the risk of chronic inflammatory diseases, all had values outside the standards established for human nutrition, namely less than 4 for $\mathrm{n}-6: \mathrm{n}-3$ and higher than 0.45 for $\mathrm{P}: \mathrm{S}$ (Wood et al., 2008).

Cholesterol concentration in muscles is closely related to its metabolic activity. More oxidative muscles have a higher tissue cholesterol concentration due to their higher phospholipid ratio (Chizzolini et al., 1999). Of the muscles studied, BF has the highest oxidative metabolic characteristics. The Longissimos dorsi and SM are considered as intermediate metabolic muscles (they have high glycolytic and oxidative activity) (Briand et al., 1981). Triceps brachii is characterized, depending on the muscle fraction analyzed (caput longum or laterale), as having intermediate to oxidative metabolism (Ithurralde et al., 2015). Thus, the grouping tendency of LD, SM, and TB muscles in the same category of metabolic activity might account for the absence of variation in the cholesterol concentration among these muscles, and their differentiation relative to the $\mathrm{BF}$, as evidenced with the cottonseed diet (Table 7).

The lower tissue cholesterol concentration promoted by the castor cake diet compared with other diets (Table 7) might not be directly related to its fatty acid profile. According to Majewska et al. (2016), dietary fatty acids in sheep have little or no relation to the tissue cholesterol concentration, but have a direct effect on the plasma. The cholesterol concentration in the plasma membrane is closely related to the intracellular transport of ricin. Grimmer et al. (2000) reported that the removal of cholesterol from the plasma membrane reduces the endocytosis of ricin (which, once inside the cell, shows a toxic effect), in addition to increasing its degradation by $40 \%$.

Thus, the possible residual presence of ricin in castor cake, even after detoxification treatment, might have promoted modifications in tissue synthesis of cholesterol to reduce endocytosis and increase ricin degradation.

\section{Conclusions}

Of the co-products investigated in this study, sunflower meal is the most suitable for replacing conventional concentrate, providing meat with lower concentrations of n-6 PUFA without reducing the levels of n-3 PUFA as observed in the castor cake diet. In addition, the meat from Longissimus dorsi muscle has the lowest fat quality indexes (e.g., conjugated linoleic acid and P:S ratio), as well as the highest saturated fatty acid levels. We found that the more oxidative muscles (e.g., Biceps femoris muscle) tend to generate cholesterol-rich meats.

\section{Acknowledgments}

We wish to thank the Pró-reitoria de Pesquisa, Pósgraduação e Inovação (PRPGI/IFBA), for the financial support for publication of this article; the Programa de Pós-graduação em Zootecnia (PPZ/UESB), for allowing the development of work; and the Grupo de Bioenergia e Meio Ambiente (BIOMA/UESC), for support in the chromatographic analyses of fatty acids.

\section{References}

Alves, F. J. L.; Ferreira, M. A.; Urbano, A. S.; Andrade, R. P. X.; Silva, A. E. M.; Siqueira, M. C. B.; Oliveira, J. P. F. and Silva, J. L. 2016. Performance of lambs fed alternative protein sources to soybean meal. Revista Brasileira de Zootecnia 45:145-150. https://doi.org/10.1590/S1806-92902016000400001

Bichi, E.; Toral, P. G.; Hervás, G.; Frutos, P.; Gómez-Cortés, P.; Juárez, M. and Fuente, M. A. 2012. Inhibition of $\Delta 9$-desaturase activity with sterculic acid: Effect on the endogenous synthesis of cis-9 18:1 and cis-9, trans-11 18:2 in dairy sheep. Journal of Dairy Science 95:5242-5252. https://doi.org/10.3168/jds.2012-5349

Bligh, E. G. and Dyer, W. J. 1959. A rapid method of total lipid. Extraction and purification. Canadian Journal of Biochemistry and Physiology 37:911-917.

Briand, M.; Talmant, A.; Briand, Y.; Monin, G. and Durand, R. 1981. Metabolic types of muscle in the sheep: II. Lactate dehydrogenase activity and LDH isoenzyme distribution. European Journal of Applied Physiology 46:359-365. https://doi.org/10.1007/ BF00422123

Cao, J.; Blond, J. and Bézard, J. 1993. Inhibiton of fatty acid $\Delta 6$ - and $\Delta 5$-desaturation by cyclopropene fatty acids in rat liver microsomes. Biochimica et Biophysica Acta 1210:27-34.

Chizzolini, R.; Zanardi, E.; Dorigoni, V. and Ghidini, S. 1999. Caloric value and cholesterol contente of normal and low-fat meat and meat products. Trends in Food Science \& Technology 10:119-128.

Choi, S. H.; Gang, G. O.; Sawyer, J. E.; Johnson, B. J.; Kim, K. H.; Choi, C. W. and Smith, S. B. 2013. Fatty acid biosynthesis and lipogenic enzyme activities in subcutaneous adipose tissue of feedlot steers fed supplementary palm oil or soybean oil. Journal of Animal Science 91:2019-2098. https://doi.org/10.2527/jas.2012-5801

Enser, M.; Hewitt, K. H. B.; Fursey, G. A. J. and Wood, J. D. 1996. Fatty acid content and composition of english beef, lamb and pork at retail. Meat Science 42:443-456. https://doi.org/10.1016/03091740(95)00037-2 
Folch, J.; Lees, M. and Stanley, G. H. S. 1957. A simple method for the isolation and purification of total lipids from animal tissues. Journal of Biological Chemistry 226:497-509.

Gomide, L. A. M.; Ramos, E. M. and Fontes, P. R. 2013. Ciência e qualidade da carne: fundamentos. Editora UFV, Viçosa, MG.

Grimmer, S.; Iversen, T. G.; Van Deurs, B. and Sandvig, K. 2000. Endosome to golgi transport of ricin is regulated by cholesterol. Molecular Biology of the Cell 11:4205-4216. https://doi.org/10.1091/ mbc.11.12.4205

ISO - International Organization for Standardization. 1978. Animal and vegetable fats and oils - Preparation of methyl esters of fatty acids (Method ISO 5509). ISO, Geneve.

Ithurralde, J.; Bianchi, G.; Feed, O.; Nan, F.; Garibotto, G. and Bielli, A. 2015. Histochemical fiber types in 16 heavy-lamb skeletal muscles. Small Ruminant Research 125:88-92. https://doi.org/ 10.1016/j.smallrumres.2015.02.006

Johnsen, L.; Kongsted, A. H. and Nielsen, M. O. 2013. Prenatal undernutrition and postnatal overnutrition alter thyroid hormone axis function in sheep. Journal of Endocrinology 216:389-402.

Koba, K. and Yanagita, T. 2014. Health benefits of conjugated linoleic acid (CLA). Obesity Research \& Clinical Practice 8:525-532. https://doi.org/10.1016/j.orcp.2013.10.001

Lands, B. 2014. Historical perspectives on the impact of n-3 and n-6 nutrients on health. Progress in Lipid Research 55:17-29. https://doi.org/10.1016/j.plipres.2014.04.002

Majewska, M. P.; Pajak, J. J.; Skomiał, J. and Kowalik, B. 2016. The effect of different forms of sunflower products in diets for lambs and storage time on meat quality. Animal Feed Science and Technology 222:227-235. https://doi.org/10.1016/j.anifeedsci.2016.10.007

Nafikov, R. A. and Beitz, D. C. 2007. Carbohydrate and lipid metabolism in farm animals. The Journal of Nutrition 137:702-705. https://doi.org/10.1093/jn/137.3.702

NRC - National Research Council. 2007. Nutrient requeriments of small ruminants. National Academy Press, Washington, DC, USA.

Paim, T. P.; Viana, P.; Brandão, E.; Amador, S.; Barbosa, T.; Cardoso, C.; Dantas, A. M. M.; Souza, J. R.; McManus, C.; Abdalla, A. L. and Louvandini, H. 2014. Carcass traits and fatty acid profile of meat from lambs fed different cottonseed by-products. Small Ruminant Research 116:71-77. https://doi.org/10.1016/j.smallrumres.2013.11.004

Saldanha, T.; Sawaya, A. C. H. F.; Eberlin, M. N. and Bragagnolo, N. 2006. HPLC separation and determination of 12 cholesterol oxidation products in Fish: Comparative study of RI, UV, and APCI-MS detectors. Journal of Agricultural Food Chemistry 54:4107-4113. https://doi.org/10.1021/jf0532009

Satterthwait, F. E. 1946. An approximate distribution of estimates of variance components. Biometrics Bulletin 2:110-114. https:// doi.org/10.2307/3002019

Schwab, U. S.; Maliranta, H. M.; Sarkkinen, E. S.; Savolainen, M. J.; Kessniemi, Y. A. and Uusitupa, M. I. J. 1996. Different effects of palmitic and stearic acid-enriched diets on serum lipids and lipoproteins and plasma cholesteryl ester transfer protein activity in healthy young women. Metabolism 45:143-149.

Silva, A. M. 2015. Qualidade da carne de cordeiros Dorper x Santa Inês submetidos a dietas contendo alimentos alternativos. Tese (D.Sc.). Universidade Estadual do Sudoeste da Bahia, Itapetinga.

Smith, S. B.; Gill, C. A.; Lunt, D. K. and Brooks, M. A. 2009. Regulation of fat and fatty acid composition in beef cattle. Asian-Australasian Journal of Animal Sciences 22:1225-1233. https://doi.org/10.5713/ajas.2009.r.10

Wood, J. D.; Enser, M.; Fisher, A. V.; Nute, G. R.; Sheard, P. R.; Richardson, R. I.; Hughes, S. I. and Whittington, F. M. 2008. Fat deposition, fatty acid composition and meat quality: A review. Meat Science 78:343-358. https://doi.org/10.1016/j.meatsci.2007.07.019

Wood, J. D.; Richardson, R. I.; Nute, G. R.; Fisher, A. V.; Campo, M. M.; Kasapidou, E.; Sheard, P. R. and Enser, M. 2003. Effects of fatty acids on meat quality: a review. Meat Science 66:21-32. https://doi.org/10.1016/S0309-1740(03)00022-6

Zock, P. L.; De Vries, J. H. M. and Katan, M. B. 1994. Impact of myristic acid versus palmitic acid on serum lipid and lipoprotein levels in healthy women and men. Arteriosclerosis and Thrombosis 14:567-575.

Zong, G.; Li, Y.; Wanders, A. J.; Alssema, M.; Zock, P. L.; Willett, W. C.; Hu, F. B. and Sun, Q. 2016. Intake of individual saturated fatty acids and risk of coronary heart disease in US men and women: two prospective longitudinal cohort studies. BMJ 355:i5796. https://doi.org/10.1136/bmj.i5796 